Jap. J. Physiol., 21, 691-708, 1971

\title{
EFFECTS OF CATECHOLAMINES ON THE GUINEA-PIG VAS DEFERENS IN VARIOUS IONIC ENVIRONMENTS
}

\author{
Tetsuo Magaribuchi, Yushi Ito and Hiroshi Kuriyama \\ Department of Physiology, Faculty of Dentistry, Kyushu University, Fukuoka 812, Japan
}

Summary Effects of externally applied noradrenaline and isoprenaline on the electrical and mechanical activities of the guinea-pig vas deferens were observed using the double sucrose gap method.

1. Noradrenaline $\left(10^{-8}-10^{-5} \mathrm{~g} / \mathrm{ml}\right)$ depolarized the membrane, reduced the membrane resistance, produced spike generation and brought about contraction ( $\alpha$-response). These effects were suppressed by treatment with phentolamine $\left(10^{-6}-10^{-5} \mathrm{~g} / \mathrm{ml}\right)$.

2. The $\alpha$-response is caused by increased $\mathrm{Na}$ and $\mathrm{K}$ conductances, and probably by increased $\mathrm{Ca}$ conductance also. The $\mathrm{Cl}$ ion reduced the $\alpha$-response due to high conductance of the membrane.

3. Isoprenaline $\left(10^{-7}-10^{-8} \mathrm{~g} / \mathrm{ml}\right)$ neither depolarized the membrane nor changed the membrane resistance but reduced the amplitude of the phasic contraction ( $\beta$-response) evoked by an outward current pulse. The suppression of the contraction was blocked by treatment with propranolol $\left(10^{-6} \mathrm{~g} / \mathrm{ml}\right)$.

4. Ouabain $\left(10^{-6} \mathrm{~g} / \mathrm{ml}\right)$ depolarized the membrane, reduced the membrane resistance and increased the spike frequency. Under the above conditions, effects of catecholamines were not suppressed.

5. The relationships between the membrane potential and tension development were observed using the microelectrode and double sucrose gap methods. The amplitudes of the phasic response of the contracture were closely related to membrane potential levels displaced by excess $\mathrm{K}$ ion, but the amplitudes of the tonic response were not related.

6. In excess K-Krebs solution (below $59 \mathrm{~mm}$ ), noradrenaline $\left(10^{-7}\right.$ $\left.10^{-6} \mathrm{~g} / \mathrm{ml}\right)$ and isoprenaline $\left(10^{-7}-10^{-6} \mathrm{~g} / \mathrm{ml}\right)$ were similar to those observed in $5.9 \mathrm{~mm}$ K-Krebs. When external $\mathrm{Na}$ ion was removed, however, the effects of noradrenaline and isoprenaline were absent.

7. If K-Krebs solution was in excess (above $59 \mathrm{~mm}$ ), the amplitude of the tonic response of the contracture was less than $20 \%$ of the amplitude

Received for publication September 28, 1971

曲淵徹雄, 伊東祐之, 栗山 熙 
of the phasic response. Noradrenaline $\left(10^{-8}-10^{-9} \mathrm{~g} / \mathrm{ml}\right)$ and isoprenaline $\left(10^{-6}-10^{-5} \mathrm{~g} / \mathrm{ml}\right)$ did not have any marked effect on electrical and mechanical properties of the muscle.

8. Acetylcholine $\left(10^{-7}-10^{-6} \mathrm{~g} / \mathrm{ml}\right)$ had effects similar to those of noradrenaline on the normal and depolarized muscle.

9. Possible actions of noradrenaline and isoprenaline in the normal and depolarized muscles were discussed in relation to the electrical and mechanical properties of the guinea-pig taenia coli.

In response to hypogastric nerve stimulation, guinea-pig vas deferens evokes excitatory junction potentials (EJP) which are thought to be due to release of noradrenaline from nerve terminals. It has been postulated that generation of EJP is due to increases in ionic conductances in the post junctional smooth muscle membrane, although it is difficult to detect changes in membrane conductance during the EJP because of the syncytial structure of smooth muscle cells (see reviews of BuRnSTOCK and Holman, 1966; Holman, 1970).

Holman and Jowett (1964), TAKagi and TAKayanagi (1965) and LARge (1965) suggested from their observations that both sympathetic $\alpha$-and $\beta$-receptors are present in the guinea-pig vas deferens. It was noted that exposure of the vas deferens to low concentrations of noradrenaline may depress transmission and that

this effect is considerably stronger in the presence of an $\alpha$-adrenergic blocking agent. Therefore, excitatory effects of noradrenaline may be mediated by $\alpha$ receptors and inhibitory effects by $\beta$-receptors which stabilize the cell membrane. Application of exogenous noradrenaline to the vas deferens produced depolarization of the membrane and contraction. However, it required much higher concentrations to elicit reproducible contraction than that competent to be released from the hypogastric nerve terminals. Therefore, it might be difficult to compare the effects of exogenous noradrenaline to noradrenaline released from the nerve terminals. For instance, Hотта (1969) assumed the presence of two different kinds of adrenergic receptors in the vas deferens, "junctional" and "extrajunctional." While the extrajunctional receptors are typical $\alpha$-type receptors, the junctional receptors are resistant to both $\alpha$ - and $\beta$-blocking agents, and seem to be desensitized by noradrenaline.

The present experiments were carried out to investigate the ionic mechanism involved in the effects of exogenously applied catecholamines (noradrenaline and isoprenaline) on the guinea-pig vas deferens in various ionic environments. The results indicate that noradrenaline increased $\mathrm{Na}, \mathrm{K}$ and $\mathrm{Ca}$ conductances and depolarized the membrane ( $\alpha$-response). Isoprenaline induced relaxation of the muscle tone or suppression of the phasic tension without any remarkable changes in the membrane resistance ( $\beta$-response). In the muscle depolarized by excess $\mathrm{K}$ ion, the effects of catecholamines could be estimated from those observed in normal saline. The mechanisms involved in the $\alpha$ - and $\beta$-effects of catecholamines 
on membrane properties and excitation-contraction coupling of the guinea-pig vas deferens were discussed.

\section{METHODS}

Male guinea-pigs weighing $250-350 \mathrm{~g}$ were stunned and bled. The vas deferens (20-25 $\mathrm{mm}$ in length) was excised from the abdomen and placed in Krebs solution. The connective tissue and the hypogastric nerve trunk were dissected longitudinally.

The double sucrose gap method was the same as that described by KURIYAMA and TомітA (1970), in which a small portion in the central part of the tissue was exposed to the test solution and the remaining parts of both sides were perfused with isotonic sucrose solution ( $90 \mathrm{~g}$ of solid sucrose dissolved in $1000 \mathrm{cc}$ of distilled deionized water). Pulses of current were applied (through a resister of $50 \mathrm{M} \Omega$ ) in the sucrose solution on one side and across the tissue. Changes in membrane potential in the central part were recorded across the sucrose gap on the other side of the tissue. Changes in isometric tension were recorded with a strain gauge attached to the end of the tissue strip on the side that was stimulated.

To observe the relationship between the membrane potential and the amplitude of the phasic and tonic contracture brought about by the depolarization of the membrane, the membrane potentials were also measured by microelectrodes filled with $3 \mathrm{M} \mathrm{KCl}$ under various ionic environments.

A modified Krebs solution of the following composition was used (mM): $\mathrm{Na}^{+}, 137.4 ; \mathrm{K}^{+}, 5.9 ; \mathrm{Mg}^{++}, 1.2 ; \mathrm{Ca}^{++}, 2.5 ; \mathrm{Cl}^{-}, 134.0 ; \mathrm{HCO}_{3}^{-}, 15.5 ; \mathrm{H}_{2} \mathrm{PO}_{4}$, 1.2 ; and glucose, 11.5; equilibrated with $97 \% \mathrm{O}_{2}$ and $3 \% \mathrm{CO}_{2}$. The Na-free solution was prepared by replacing $\mathrm{NaCl}$ and $\mathrm{NaHCO}_{3}$ with tris-Cl. The $\mathrm{pH}$ of the solution was kept at 7.2-7.3. Isotonic excess $\mathrm{K}$-solutions were prepared by increasing $\mathrm{KCl}$ and $\mathrm{KHCO}_{3}$ concentrations with equivalent reduction of the concentrations of $\mathrm{NaCl}$ and $\mathrm{NaHCO}_{3}$. The Na-free excess $\mathrm{K}$-solutions were prepared by isotonic increase of $\mathrm{KCl}$ and $\mathrm{KHCO}_{3}$ concentrations with equivalent reduction of the concentration of tris- $\mathrm{Cl}$.

Drugs used in the present experiment were $l$-noradrenaline $\mathrm{HCl}, d l$-isoprenaline $\mathrm{HCl}$, acetylcholine- $\mathrm{Cl}$ and ouabain. As $\alpha$ - and $\beta$-blocking agents, phentolamine and propranolol were used, respectively. The experiments were carried out at $35 \pm 1{ }^{\circ} \mathrm{C}$. For the application of noradrenaline and isoprenaline, one end of a small vinyl tubule (diameter $0.5 \mathrm{~mm}$ ) was connected into the vinyl tube used for the perfusion of the test solutions. The another end of the tubule was attached to the injection syringe $(1 \mathrm{cc})$. Noradrenaline and isoprenaline were diluted to the required concentration with the test solution. By this procedure, $0.1 \mathrm{cc}$ of injected noradrenaline or isoprenaline was in contact with the tissue for only 2-3 sec. The concentrations of drugs are described in the results and indicate the final concentration. Acetylcholine- $\mathrm{Cl}$ was applied to the tissue in the same manner. 


\section{RESULTS}

\section{Effects of catecholamines in Krebs solution}

The membrane of the guinea-pig vas deferens was quiescent. The inward current pulse $(3 \mathrm{sec})$ evoked an electrotonic potential and break excitation. The outward current pulse $(3 \mathrm{sec})$ generated the burst discharges on the electrotonic potential and phasic contraction.

Figure 1 shows the effects of applications of successive inward and outward current pulses on the smooth muscle. In this preparation, the linear relationship between the applied current intensities and evoked hyperpolarization of the membrane was limited to a narrow range (from $2 \times 10^{-8} \mathrm{~A}$ to $1 \times 10^{-7} \mathrm{~A}$ ) and outward current pulses produced marked rectification of the membrane. When spikes were generated by outward current pulses $\left(1-2 \times 10^{-7} \mathrm{~A}\right)$, the membrane properties were transiently modified after generation of the spikes, e.g. even after $20 \mathrm{sec}$ the membrane resistance was reduced and the generation of the break excitation was suppressed. Relaxation after the cessation of the outward current pulses appeared more rapidly in the vas deferens $(7-15 \mathrm{sec})$ than in the taenia coli $(12-28 \mathrm{sec})$. However, these data obtained from the two tissues may not be comparable, since outward current pulse evoked repeated spike discharges in the vas deferens (Figs. 1, 2 and 13) which does not usually occur in taenia coli.
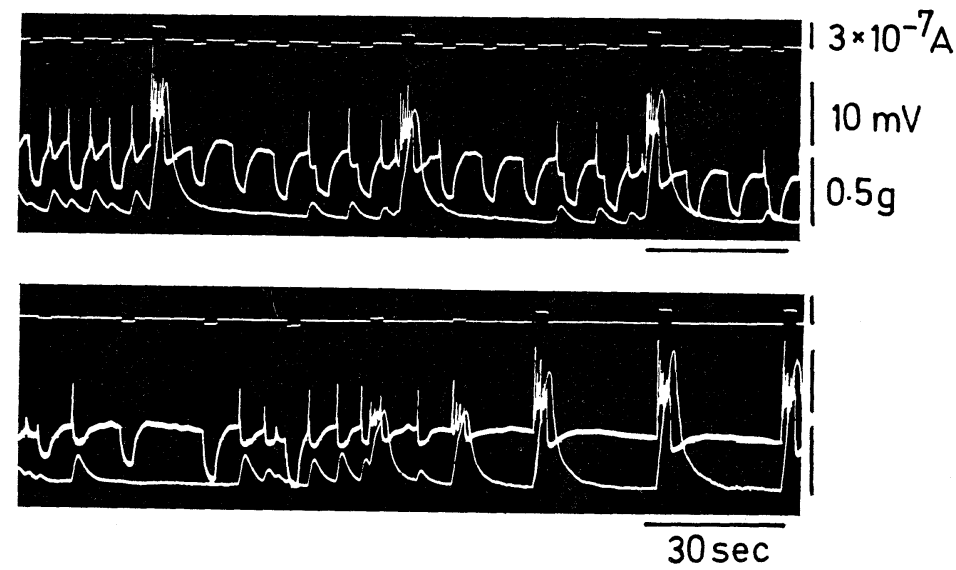

Fig. 1. Effects of various intensities of inward and outward current pulses $(3 \mathrm{sec})$ on the guinea-pig vas deferens. Top line in record: current monitor. Middle line: membrane potential changes. Bottom line: muscle tone.

Figure 2 shows a typical example of the effects of noradrenaline $\left(10^{-7} \mathrm{~g} / \mathrm{ml}\right)$ and isoprenaline $\left(10^{-7} \mathrm{~g} / \mathrm{ml}\right)$ on the electrical and mechanical activities of the guineapig vas deferens. Noradrenaline depolarized the membrane, reduced the membrane resistance, generated spike discharges and evoked phasic contraction. On 

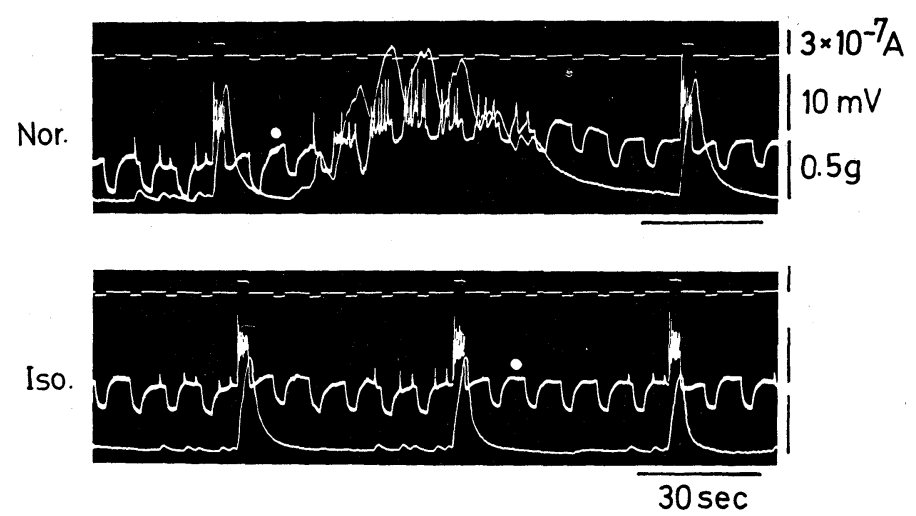

Fig. 2. Effects of noradrenaline $\left(10^{-7} \mathrm{~g} / \mathrm{ml}\right)$ and isoprenaline $\left(10^{-7} \mathrm{~g} / \mathrm{ml}\right)$ on electrical and mechanical activities. Nor: noradrenaline. Iso: isoprenaline. $\bigcirc$ : applications of catecholamine.
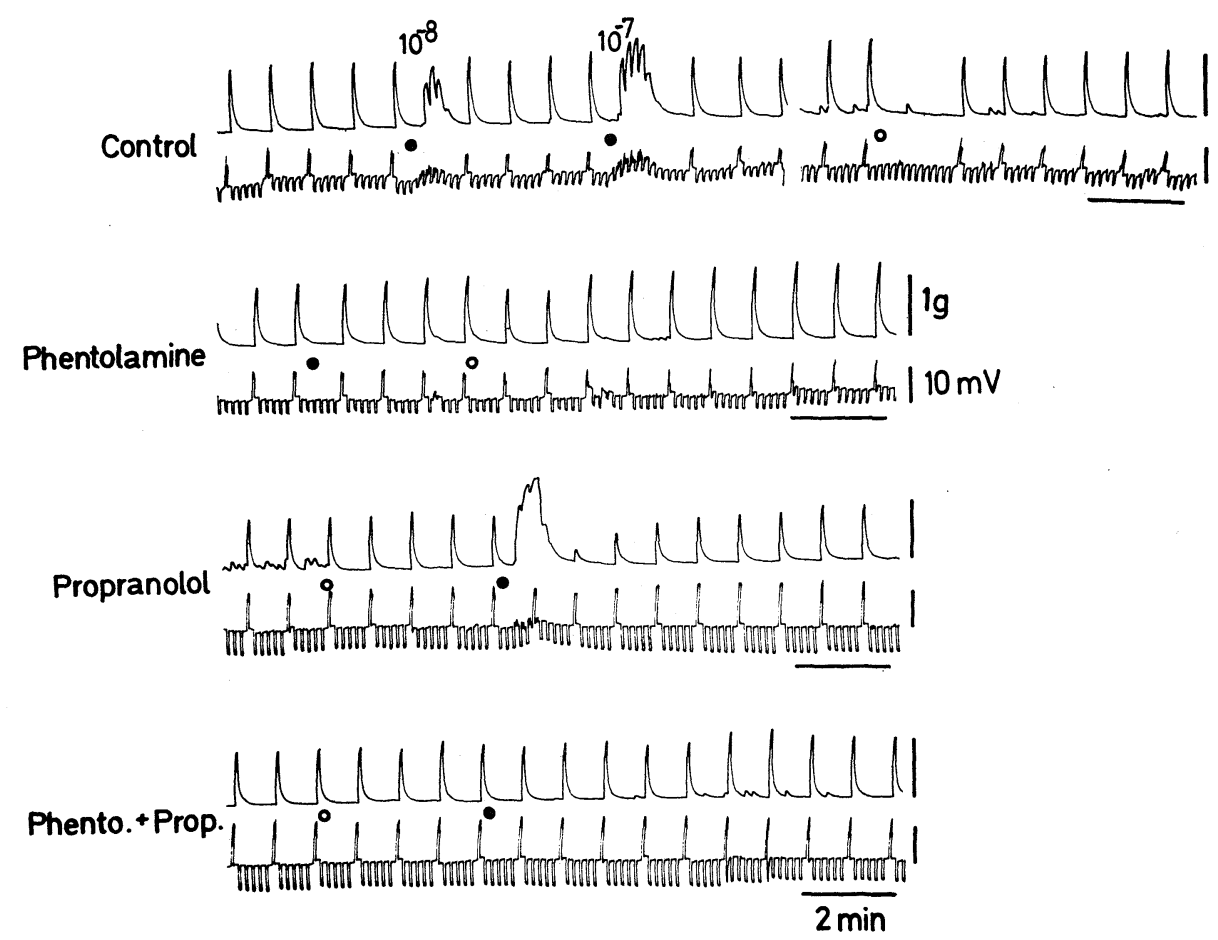

Fig. 3. Effects of noradrenaline $(\bullet)$ and isoprenaline $(O)$ on electrical and mechanical activities under pretreatment with phentolamine $\left(10^{-6} \mathrm{~g} / \mathrm{ml}\right)$ and propranolol $\left(10^{-6} \mathrm{~g} /\right.$ $\mathrm{ml}$ ). Concentration of noradrenaline and isoprenaline: $10^{-7} \mathrm{~g} / \mathrm{ml}$ (except for the control). Inward current pulse: $1 \times 10^{-7} \mathrm{~A}$; outward current pulse: $2 \times 10^{-7} \mathrm{~A}$. Upper record: mechanical changes. Lower record: electrical changes. 
the other hand, isoprenaline neither depolarized nor reduced the membrane resistance but the amplitude of the phasic contraction generated by the outward current pulse was suppressed. The effects of catecholamines were modified by treatment with adrenergic blocking agents. The effect of noradrenaline $\left(10^{-7}\right.$ $\mathrm{g} / \mathrm{ml})$ was completely suppressed by treatment with phentolamine $\left(10^{-6} \mathrm{~g} / \mathrm{ml}\right)$, but the effect of isoprenaline $\left(10^{-7} \mathrm{~g} / \mathrm{ml}\right)$ was not. The effect of isoprenaline $\left(10^{-7} \mathrm{~g} / \mathrm{ml}\right)$ was suppressed by treatment with propranolol $\left(10^{-6} \mathrm{~g} / \mathrm{ml}\right)$, but the effects of noradrenaline were not influenced by $\beta$-blockade. Simultaneous treatment with phentolamine $\left(10^{-6} \mathrm{~g} / \mathrm{ml}\right)$ and propranolol $\left(10^{-6} \mathrm{~g} / \mathrm{ml}\right)$ completely abolished the effects of noradrenaline $\left(10^{-7} \mathrm{~g} / \mathrm{ml}\right)$ and isoprenaline $\left(10^{-7} \mathrm{~g} / \mathrm{ml}\right)$ (Fig. 3). The above results are compatible with two receptors distributed in the guinea-pig vas deferens, the excitatory action due to an $\alpha$-response and the inhibitory action due to a $\beta$-response. Noradrenaline possesses mainly an $\alpha$-effect, and isoprenaline a $\beta$-effect.

\section{Effects of catecholamines in modified Krebs solution}

To investigate the effects of catecholamines in relation to the ionic properties of the membrane, $\mathrm{Na}, \mathrm{K}$ and $\mathrm{Cl}$ ion concentrations were modified in Krebs solution.

Figure 4 shows the effects of noradrenaline $\left(10^{-6} \mathrm{~g} / \mathrm{ml}\right)$ and isoprenaline $\left(10^{-6} \mathrm{~g} / \mathrm{ml}\right)$ in Na-free (tris) Krebs solution and in Cl-deficient Krebs solution (7.4 mM Cl ion remained as $\mathrm{CaCl}_{2}$ and $\mathrm{MgCl}_{2}$, and $\mathrm{NaCl}$ and $\mathrm{KCl}$ were replaced by $\mathrm{NaC}_{6} \mathrm{H}_{5} \mathrm{SO}_{3}$ and $\mathrm{KC}_{6} \mathrm{H}_{5} \mathrm{SO}_{3}$ respectively). In the Na-free (tris) solution, the membrane was hyperpolarized $(6-12 \mathrm{mV}, n=4)$ and the membrane resistance was reduced (0.68-0.79 times the control value in Krebs solution, $n=4)$. These phenomena were the same as observed previously in the taenia coli (BRADING et al. 1969) and stomach circular muscle (SAKAмOTo and KuriYAmA, 1971). Administration of noradrenaline $\left(10^{-7}-10^{-6} \mathrm{~g} / \mathrm{ml}\right)$ or isoprenaline $\left(10^{-7}-10^{-6} \mathrm{~g} / \mathrm{ml}\right)$ had no effect on the electrical and mechanical activities of the smooth muscle.

In the $\mathrm{Cl}$-deficient $\mathrm{Krebs}$ solution, the membrane was depolarized (3-7 $\mathrm{mV}$, $n=4)$ and the membrane resistance was increased (1.42-1.69 times the control value, $n=4)$. Noradrenaline $\left(10^{-7} \mathrm{~g} / \mathrm{ml}\right)$ further depolarized the membrane, reduced the membrane resistance and increased the phasic contraction to levels greater than those observed in Krebs solution. When isoprenaline $\left(10^{-7} \mathrm{~g} / \mathrm{ml}\right)$ was applied to the tissue, the membrane was unexpected depolarized but the amplitude of the phasic contraction was reduced, as observed in Krebs solution. Presumably the membrane $\alpha$-response to isoprenaline was dominant in the $\mathrm{Cl}$ deficient experiments since changes in the membrane properties due to $\beta$-response of the membrane were not present. The $\beta$-response seems to effect primarily the contractile mechanism.

In the K-deficient experiments $(0.59 \mathrm{~mm}$, one-tenth the normal concentration), the membrane was slightly hyperpolarized $(2-6 \mathrm{mV}, n=3)$, membrane 

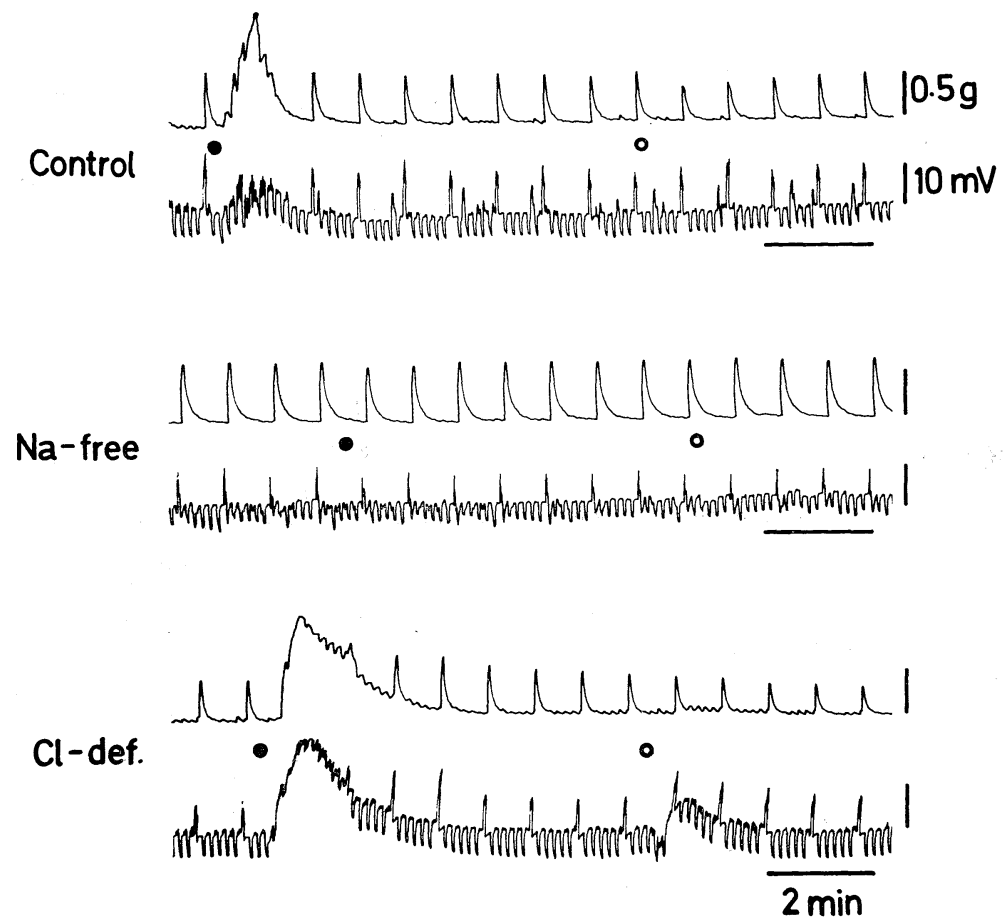

Fig. 4. Effects of noradrenaline $\left(\bullet: 10^{-6} \mathrm{~g} / \mathrm{ml}\right)$ and isoprenaline $\left(\bigcirc: 10^{-6} \mathrm{~g} / \mathrm{ml}\right)$ on the electrical and mechanical activities in Na-free (tris) $\mathrm{Krebs}$ and in the $\mathrm{Cl}$-deficient $\left(\mathrm{C}_{6} \mathrm{H}_{5^{-}}\right.$ $\mathrm{SO}_{3}$ but $7.4 \mathrm{mM} \mathrm{Cl}$ remained as $\mathrm{CaCl}_{2}$ and $\mathrm{MgCl}_{2}$ ) Krebs. Explanations for the symbols in the figure are the same as those in Fig. 3.

resistance was increased (1.21-1.07 times the control value) and amplitudes of the phasic contraction generated by the outward current pulses were reduced, although effects of noradrenaline $\left(10^{-7} \mathrm{~g} / \mathrm{ml}\right)$ and isoprenaline $\left(10^{-7} \mathrm{~g} / \mathrm{ml}\right)$ were still observed (Fig. 5).

It is known that ouabain suppresses the Na-K active transport system of the membrane (see reviews of Straub, 1967; CALDWELL, 1968). To investigate whether or not the effects of catecholamines on the smooth muscle are related to the Na-K transport system, the effects of catecholamines in the presence of ouabain were studied. Figure 6 shows the effects of catecholamines (noradrenaline and isoprenaline) on electrical and mechanical activities of the smooth muscle in the presence of ouabain $\left(10^{-6} \mathrm{~g} / \mathrm{ml}\right)$. Ouabain depolarized the membrane $(8-12 \mathrm{mV}$, $n=3)$, reduced the membrane resistance $(0.68-0.74$ times the control, $n=3$ ) and increased the spike frequency. The amplitudes of the phasic contraction generated by an outward current pulse, however, were reduced. Under treatment with ouabain, effects of noradrenaline $\left(10^{-7} \mathrm{~g} / \mathrm{ml}\right)$ and isoprenaline $\left(10^{-7}\right.$ $\mathrm{g} / \mathrm{ml}$ ) could still be observed. Furthermore, effects of noradrenaline on the phasic 
Control

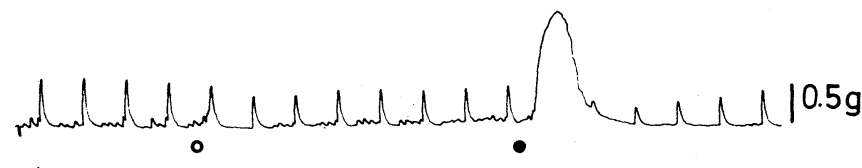

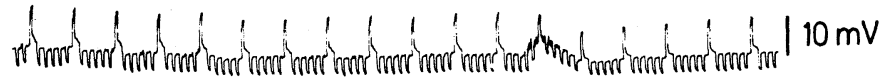

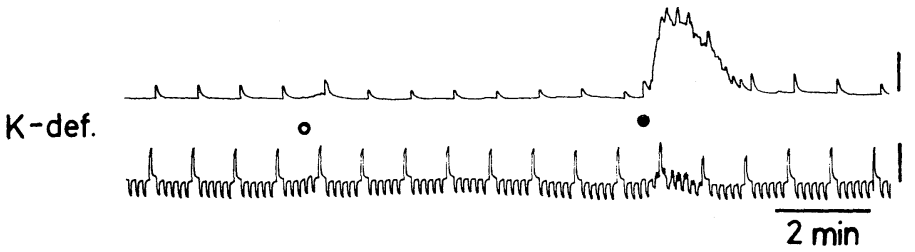

Fig. 5. Effects of noradrenaline $\left(\bullet: 10^{-7} \mathrm{~g} / \mathrm{ml}\right)$ and isoprenaline $\left(O: 10^{-7} \mathrm{~g} / \mathrm{ml}\right)$ in Krebs (control) and in the K-deficient $(0.59 \mathrm{~mm})$ Krebs. Symbols in the figure are the same as those in Fig. 3.
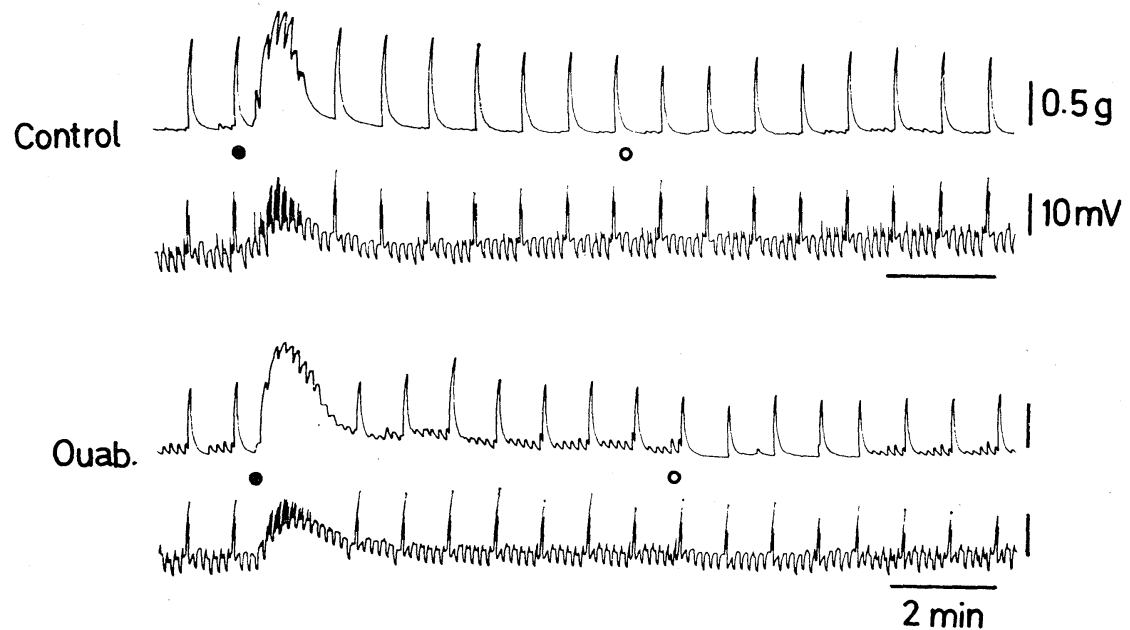

Fig. 6. Effects of noradrenaline $\left(\bullet: 10^{-7} \mathrm{~g} / \mathrm{ml}\right)$ and isoprenaline $\left(O: 10^{-7} \mathrm{~g} / \mathrm{ml}\right)$ on the electrical and mechanical activities under pretreatment with ouabain $\left(10^{-6} \mathrm{~g} / \mathrm{ml}\right)$.

contraction evoked by electrical stimulation were enhanced. Effects of catecholamines were also observed in following simultaneous applications of ouabain $\left(10^{-6} \mathrm{~g} / \mathrm{ml}\right)$ and K-deficiency $(0.59 \mathrm{mM})$. Potassium deficiency is also thought to suppress the $\mathrm{Na}-\mathrm{K}$ active transport system. In the above solution, effects of noradrenaline $\left(10^{-7} \mathrm{~g} / \mathrm{ml}\right)$ and isoprenaline $\left(10^{-7} \mathrm{~g} / \mathrm{ml}\right)$ could still be observed. 
Effects of catecholamines in the depolarized smooth muscle produced by excess K-Krebs

In the guinea-pig taenia coli, isotonic K-Krebs solution depolarizes the membrane and evokes contracture of the muscle. The contracture of the muscle has two components: the initial phasic response and a tonic response. In the phasic response, the $\mathrm{Ca}$ ion is thought to be released from an intracellular site, whereas in the tonic response $\mathrm{Ca}$ probably crosses the membrane (URAKAWA and Holland, 1964). On the other hand, IMAI and TAKeda (1967) concluded that the phasic response and a part of the tonic response of the contracture depend upon the extracellular $\mathrm{Ca}$ for their initiation and that the rest of the tonic response draws on a store of bound $\mathrm{Ca}$ for its evolution.

With the vas deferens, the two components of the contracture could be observed under excess K-Krebs (more than $29.5 \mathrm{~mm}$ ). The initial phasic response developed rapidly because of depolarization and spiking of the membrane, and the depolarization was still present when the phasic tension started to relax. The tonic response was at an amplitude of about $20 \%$ of the phasic response.

Figure 7 shows the effects of excess K-Krebs solution (59 mM and $118 \mathrm{~mm}$ ) on the electrical and mechanical activities of the smooth muscle. When 20 times
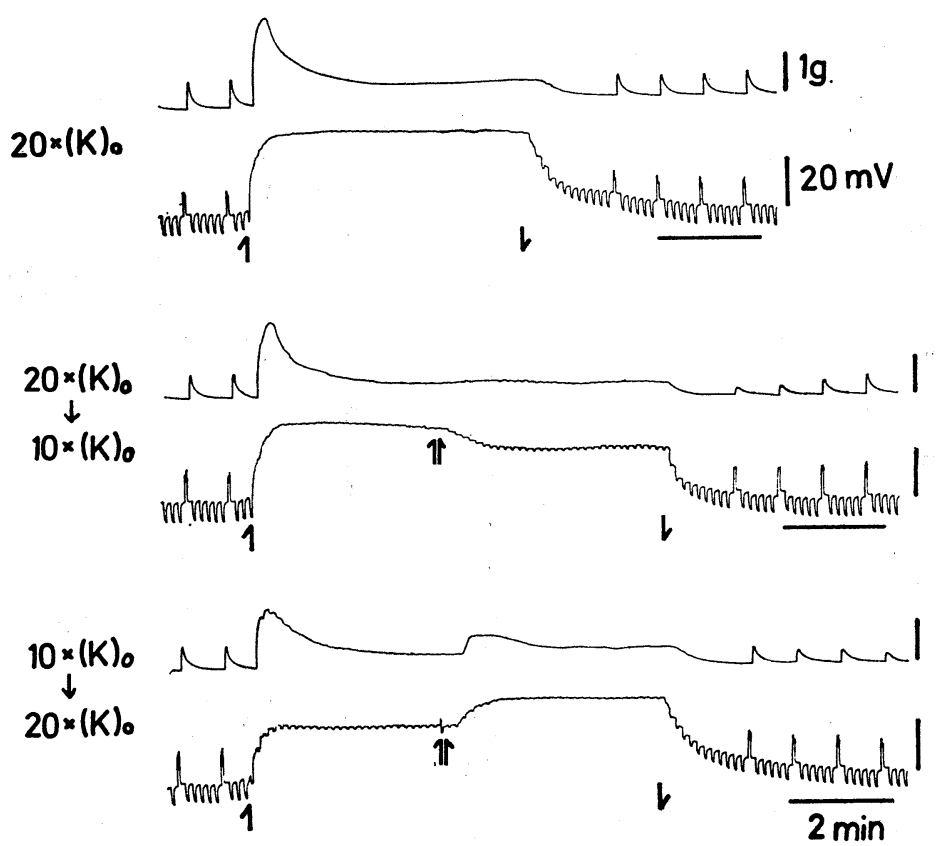

Fig. 7. Effects of excess K-Krebs (59 mM and $118 \mathrm{~mm}$ ) on the electrical and mechanical activities of the guinea-pig vas deferens. 1: application of excess $\mathrm{K}$ ion; $l$ : removal of excess $\mathrm{K}$ ion; $1 \uparrow$ : application of different concentration of excess $\mathrm{K}$ ion. 
the normal K-Krebs solution (118 $\mathrm{mm}$ ) was applied to the tissue, the membrane was markedly depolarized and membrane resistance was reduced to below one tenth the control value. When the external solution was then replaced by 10 times the normal K-Krebs solution ( $59 \mathrm{~mm} \mathrm{~K}$ ion), the membrane was repolarized

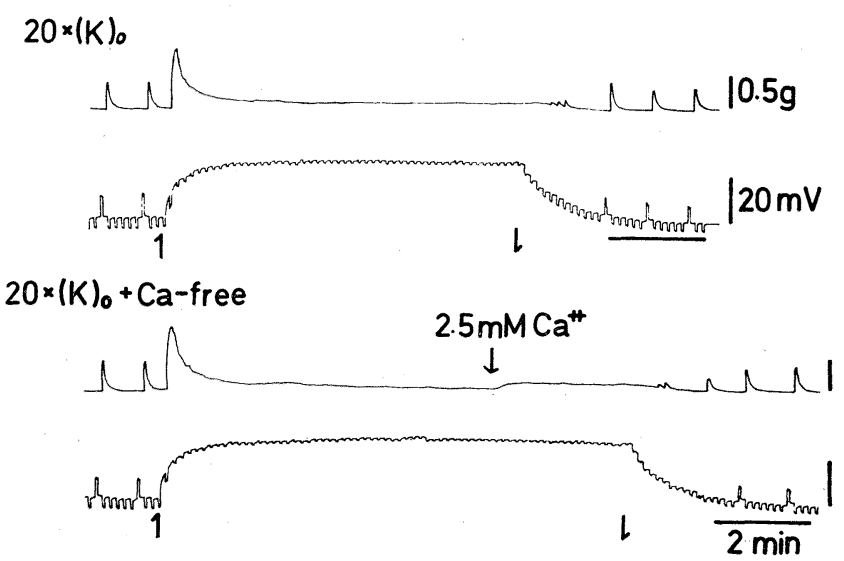

Fig. 8. Effects of excess K-Krebs (118 mm) solution with and absence of Ca ion on the electrical and mechanical activities. Symbols of figure are the same as those in Fig. 7.

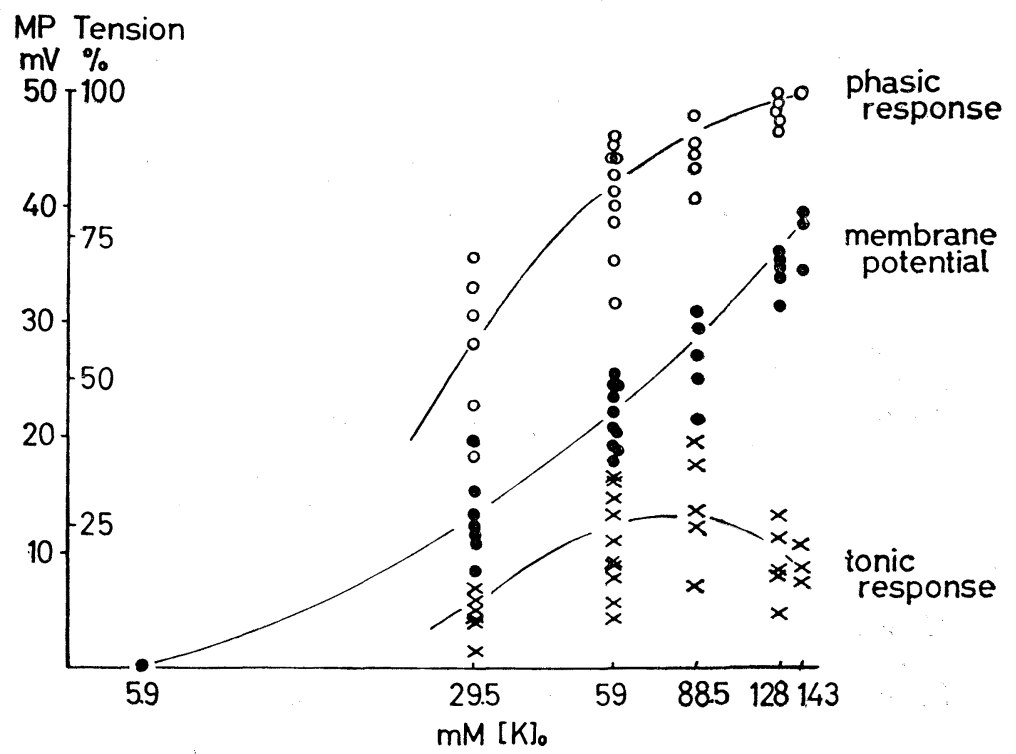

Fig. 9. Effects of various concentrations of $\mathrm{K}$ ion on the membrane potential and tension development measured by the sucrose gap method. Changes in the membrane potential and tension development (phasic and tonic response) are illustrated by relative values $(0 \mathrm{mV}$ at $5.9 \mathrm{~mm} \mathrm{KCl}$ and $100 \%$ amplitude of the tension at the peak of the phasic response evoked by $143 \mathrm{~mm}$ K-Krebs solution). 
(9 $\mathrm{mV}$ in Fig. 7) and membrane resistance was slightly increased. However, no difference in the amplitude of the tonic response was observed. When 10 times the normal K-Krebs solution was previously given, the application of 20 times the normal K-Krebs solution further depolarized the membrane and produced the phasic response of the contracture on the tonic response. However, the phasic response declined to the level before application of the 20 times the normal $\mathrm{K}$ Krebs solution.

The tonic response of $\mathrm{K}$-induced contracture was dependent on the external $\mathrm{Ca}$ ion. As shown in Fig. 8, when the tissue was perfused with Ca-free and 118 mM K-Krebs solution (20 times control), the tonic response did not appear. After further addition of the normal concentration of $\mathrm{Ca}$ ion $(2.5 \mathrm{mM})$, the amplitude of the tonic response was similar to that observed in $118 \mathrm{~mm}$ K-Krebs solution. However, no phasic response could be observed.

The relationships between the membrane potentials and tension development with various K-concentrations are illustrated in Figs. 9 and 10. Changes in the membrane potential with the various K-concentrations (5.9-143 mM) were plotted using relative values in Fig. 9 and absolute values in Fig. 10. The relative amplitudes of the contracture were compared with the amplitudes of the phasic responses evoked by the isotonic K-Krebs solution (143 mM). The phasic responses increased

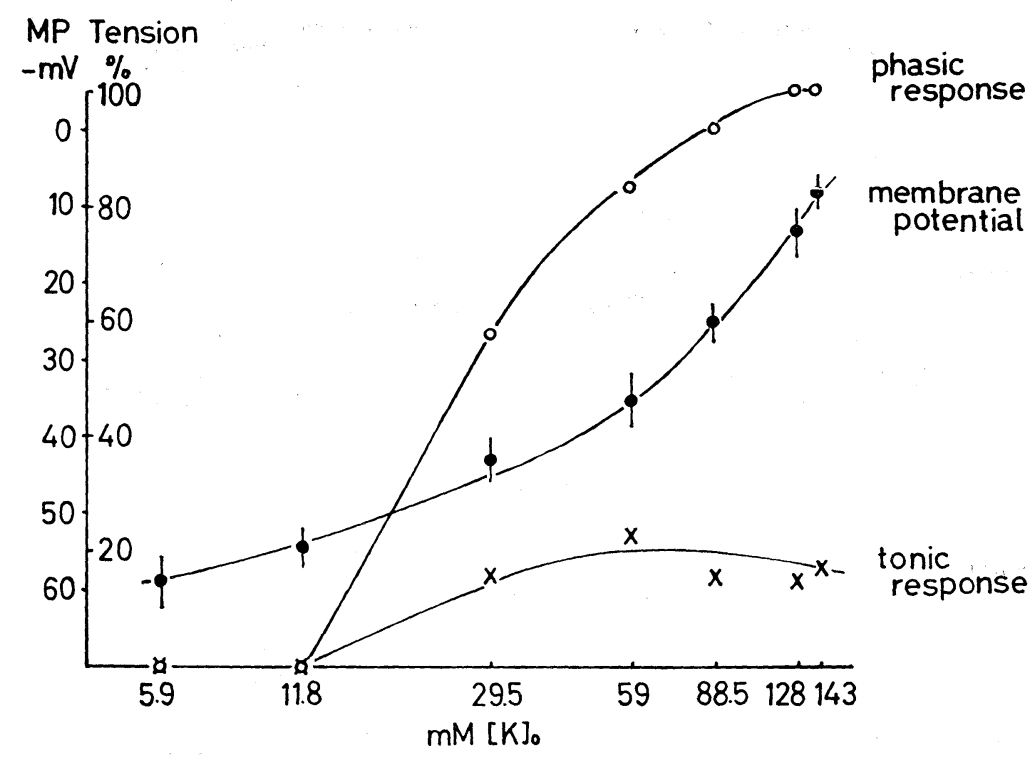

Fig. 10. Effects of various concentrations of $\mathrm{K}$ ion on the membrane potential and tension development measured by the microelectrode method. Changes in the membrane potential are illustrated by absolute values and the changes in the tension development are illustrated by relative values as described in Fig. 9. 
their amplitudes as a function of depolarization but the tonic response showed nearly the same amplitude at any given concentration of $\mathrm{K}$ ion (29.5-143 mM). The mean amplitude of the tonic response was about $20 \%$ of the phasic response evoked by isotonic $\mathrm{K}-\mathrm{Krebs}$ solution. The critical concentration of $\mathrm{K}$ ion needed to bring about a contracture was $29.5 \mathrm{~mm}$ and the membrane was depolarized to $-42 \mathrm{mV}$ (Fig. 10).

Effects of catecholamines on the electrical and mechanical activities with various K-concentrations are illustrated in Figs. 11 and 12. Figure 11 shows the effects of noradrenaline $\left(10^{-7} \mathrm{~g} / \mathrm{ml}\right)$ and isoprenaline $\left(10^{-7} \mathrm{~g} / \mathrm{ml}\right)$ in $29.5 \mathrm{~mm}(5$ times control), in $59 \mathrm{~mm}$ (10 times control) and in $118 \mathrm{~mm}$ (20 times control) $\mathrm{K}$ Krebs solution, respectively. In the excess K-Krebs solution (29.5-59 mM), noradrenaline resulted in phasic contraction due to increase of the spike frequency and reduction of the membrane resistance. Isoprenaline relaxed the amplitude of the tonic response with or without changes in spike frequency. For example, as shown in Fig. 12, isoprenaline $\left(10^{-7} \mathrm{~g} / \mathrm{ml}\right)$ relaxed the tonic response without any remarkable change in the membrane potential, membrane resistance or spike
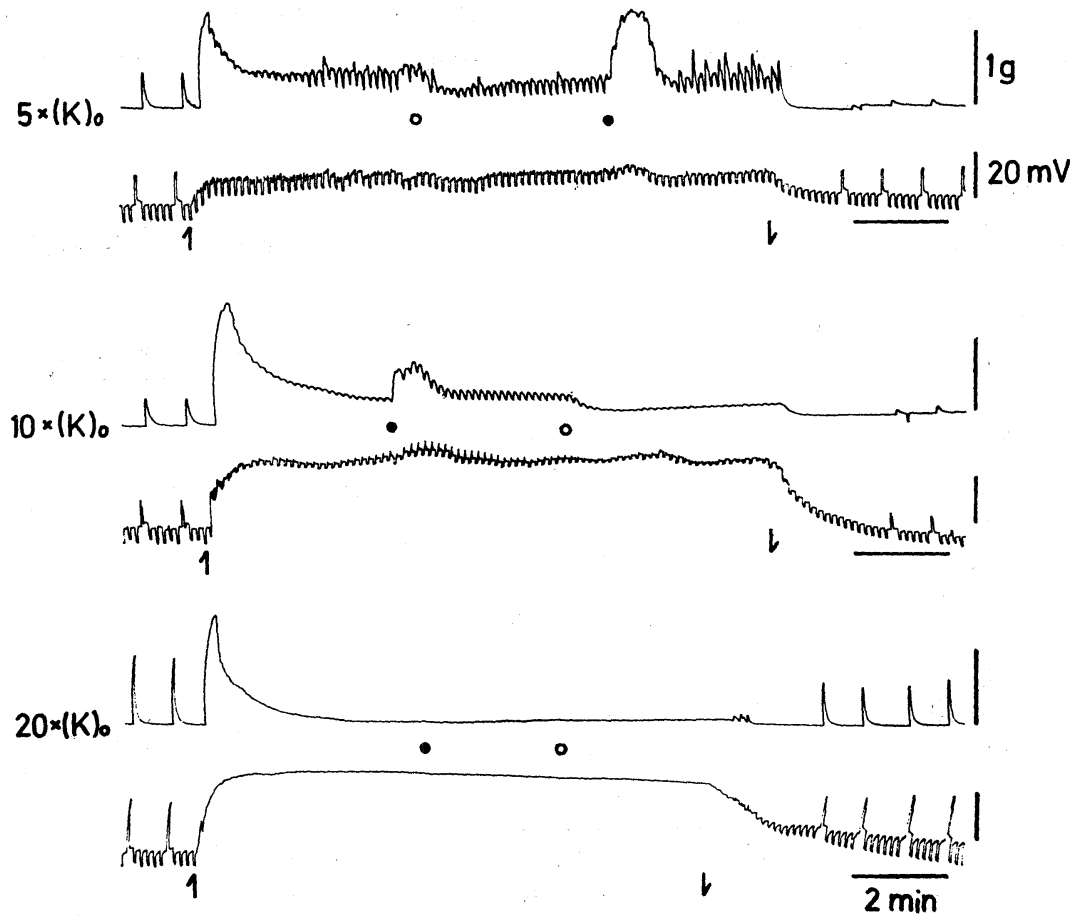

Fig. 11. Effects of noradrenaline $\left(\bullet: 10^{-7} \mathrm{~g} / \mathrm{ml}\right)$ and isoprenaline $\left(O: 10^{-7} \mathrm{~g} / \mathrm{ml}\right)$ on the electrical and mechanical activities of the depolarized smooth muscle evoked by the excess K-Krebs ( 5 times: $29.5 \mathrm{~mm}$; 10 times: $59 \mathrm{~mm}$; 20 times: $118 \mathrm{~mm}$ ). Symbols in the figure are the same as those in Fig. 3. 

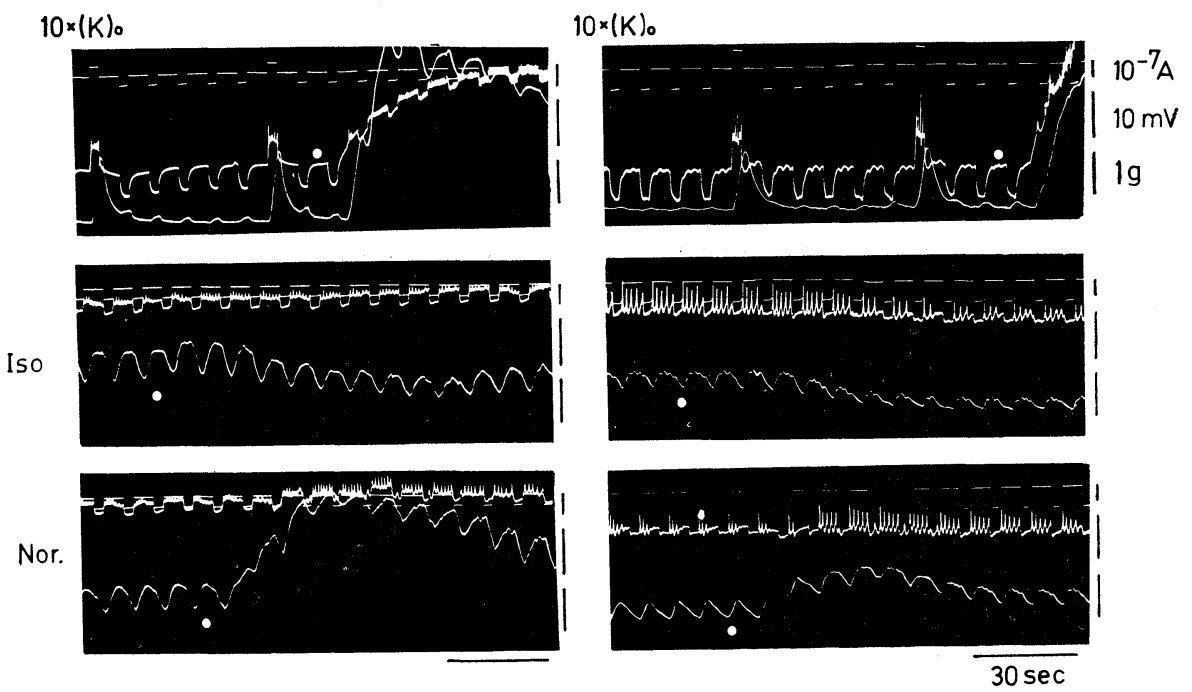

Fig. 12. Effects of noradrenaline $\left(10^{-7} \mathrm{~g} / \mathrm{ml}\right)$ and isoprenaline $\left(10^{-7} \mathrm{~g} / \mathrm{ml}\right)$ on the electrical and mechanical activities in $59 \mathrm{~mm}$ K-Krebs solution. Symbols of figure are the same as those in Fig. 2. Left and right sides of the record are taken from two different preparations.

frequency. In some preparations, however, isoprenaline $\left(10^{-7} \mathrm{~g} / \mathrm{ml}\right)$ slightly hyperpolarized the membrane and reduced the spike frequency. On the other hand, noradrenaline $\left(10^{-7} \mathrm{~g} / \mathrm{ml}\right)$ consistently reduced the membrane resistance and increased the spike frequency, thus enhancing the tension development.

When the external concentration of $\mathrm{K}$ ion increased more than ten times the normal concentration $(59 \mathrm{~mm})$, noradrenaline and isoprenaline did not influence the electrical and mechanical activities of the smooth muscle. Not only in the excess K-Krebs solution (more than $59 \mathrm{~mm}$ ) but in the Na-free (tris) excess K-Krebs solution, noradrenaline $\left(10^{-6}-10^{-7} \mathrm{~g} / \mathrm{ml}\right)$ and isoprenaline $\left(10^{-6}-10^{-7} \mathrm{~g} / \mathrm{ml}\right) \mathrm{did}$ not cause change in the electrical or mechanical activities of the muscle.

Figure 13 shows the effects of noradrenaline $\left(10^{-6} \mathrm{~g} / \mathrm{ml}\right)$ and isoprenaline $\left(10^{-6} \mathrm{~g} / \mathrm{ml}\right)$ on the $\mathrm{K}-\mathrm{Krebs}$ solutions ten times the normal and on $\mathrm{K}$ ten times the normal with Na-free Krebs solution. No remarkable effect of catecholamine was observed in the Na-free Krebs solution. These results indicate that in either normal or in excess K-concentration, catecholamines require the presence of $\mathrm{Na}$ ion to produce effects. Effects of acetylcholine on the electrical and mechanical properties in normal and in depolarized muscle were observed and compared with noraderenaline data. As shown in Fig. 14, acetylcholine $\left(10^{-7} \mathrm{~g} / \mathrm{ml}\right)$ depolarized the membrane, reduced the membrane resistance and increased the spike frequency, thus causing the development of phasic contraction. The effects of acetylcholine on smooth muscle were small compared with those observed by 


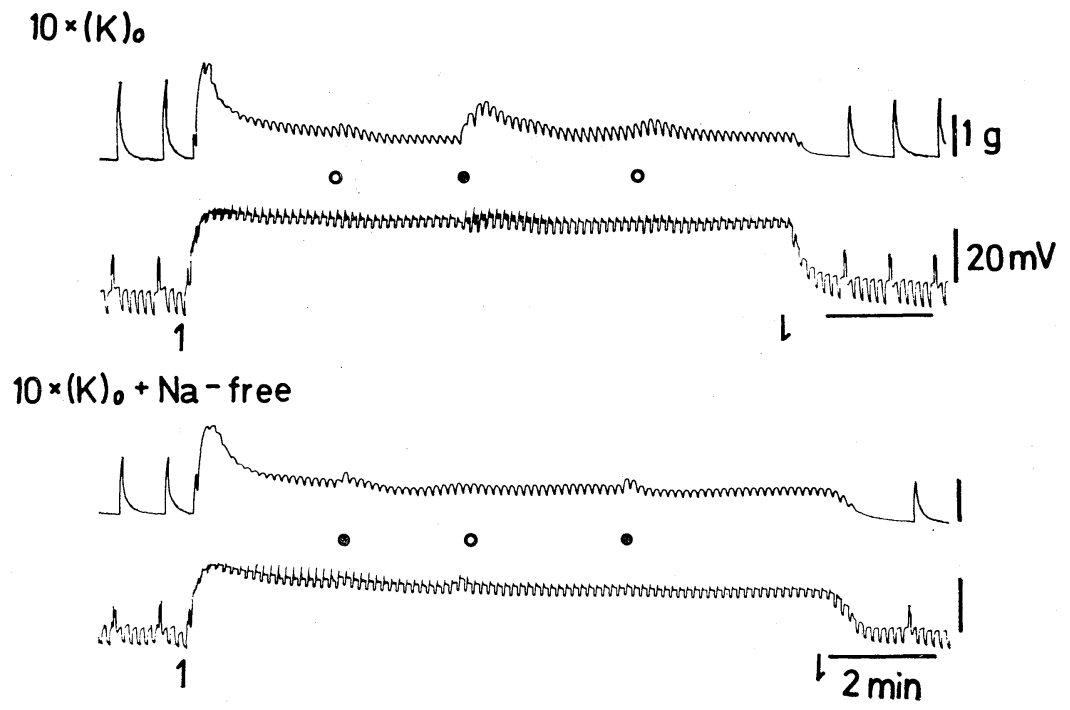

Fig. 13. Effects of noradrenaline $\left(0: 10^{-7} \mathrm{~g} / \mathrm{ml}\right)$ and isoprenaline $\left(\bigcirc: 10^{-7} \mathrm{~g} / \mathrm{ml}\right)$ in the 59 mм K-Krebs and in the Na-free (tris) $59 \mathrm{~mm} \mathrm{K-Krebs} \mathrm{solution.} \mathrm{Symbols} \mathrm{in} \mathrm{the} \mathrm{figure}$ are the same as those in Fig. 7.

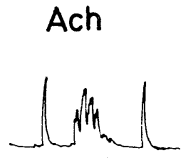

$\Delta$

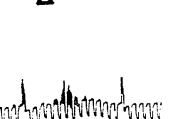

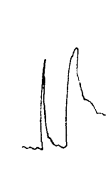

1

$20 \times(K)$ 。
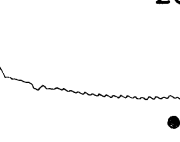

- Nor.

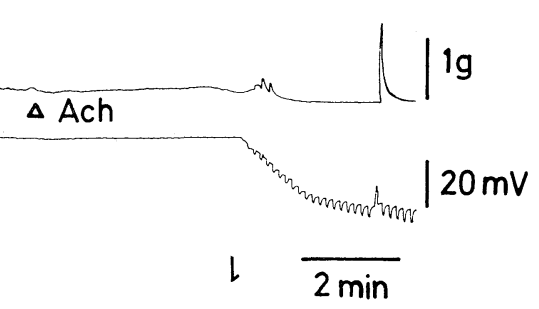

Fig. 14. Effects of acetylcholine $\left(\triangle: \mathrm{ACh}, 10^{-7} \mathrm{~g} / \mathrm{ml}\right)$ in Krebs and in $118 \mathrm{~mm} \mathrm{~K}-\mathrm{Krebs}$ solution. Effects of noradrenaline $\left(0: 10^{-7} \mathrm{~g} / \mathrm{ml}\right)$ are also observed in $118 \mathrm{~mm} \mathrm{~K}-\mathrm{Krebs}$ in comparison with those of acetylcholine. Symbols in the figure are the same as those in Fig. 7.

the application of the same concentration of noradrenaline. With administration of 20 times the excess K-Krebs solution, acetylcholine $\left(10^{-7} \mathrm{~g} / \mathrm{ml}\right)$ neither depolarized nor reduced the membrane resistance, and no change in the amplitude of the tonic response was observed, but in some preparations the amplitude of the tonic response was slightly suppressed.

\section{DISCUSSION}

The effects of noradrenaline and isoprenaline on the electrical and mechanical 
activities of the guinea-pig taenia coli under normal and in depolarized conditions were investigated by MAGARIBUCHI and KURIYAMA (1972), who concluded that noradrenaline decreased the membrane resistance at any given concentration of excess $\mathrm{K}$ ion and isoprenaline relaxed the tonic response of the contracture without any marked change in the membrane resistance, membrane potential and membrane activity at any given concentration of excess $\mathrm{K}$ ion. The action of noradrenaline is mediated mainly by $\alpha$-receptors and the action of isoprenaline, mainly $\beta$-receptors. It is thought that the former acts mainly on the membrane and the latter mainly causes a reduction in free $\mathrm{Ca}$ ion in the myoplasm presumably by increasing $\mathrm{Ca}$ ion reabsorption.

The differences in the effects of noradrenaline on the taenia coli and vas deferens can be summarized as follows: (1) Noradrenaline enhances tension development in the vas deferens but reduces it in the taenia coli. (ii) Noradrenaline reduces the membrane resistance of both tissues, but the polarity of the displacement of the membrane potential is opposite in the two tissues. (iii) In the absence of $\mathrm{Na}$ ions, no effect of noradrenaline is observed in either tissue. In the taenia coli, noradrenaline presumably increases the K-conductance (BüLBRING and TomitA, 1969a, b) but no increase of K-conductance was observed in the Nafree Krebs solution (Magaribuchi and KuriYama, 1972). In the vas deferens, noradrenaline might increase the Na- and K-conductances. However, in the $\mathrm{Na}$-free solutions no increase of K-conductance could be observed. (iv) In the excess K-Krebs solution, noradrenaline further reduces the membrane resistance of the taenia coli but no change in the tonic response is observed. However, in the vas deferens no changes in membrane resistance or tension development occur.

The effects of isoprenaline on both tissues are summarized as follows: (i) Isoprenaline causes no marked change in either tissue in the membrane resistance of the control or the muscle depolarized by excess K-Krebs (below $59 \mathrm{~mm}$ ), but relaxes the tonic response of the contracture. (ii) In the taenia coli, isoprenaline suppresses spontaneous spike generation in Krebs solution but in the vas deferens, suppression of the spontaneous spike was not an essential factor in suppression of tension development. (iii) In isotonic $\mathrm{K}$ solution, treatment with isoprenaline markedly relaxes the non-pregnant rat myometrium (SCHILD, 1967) and slightly relaxes the guinea-pig taenia coli. No relaxation occurs with the guinea-pig vas deferens. (iv) With or without the presence of oubain, isoprenaline suppresses tension development in both tissues in Krebs solution. (v) In the absence of $\mathrm{Na}$ ion, isoprenaline does not relax muscle tone in either tissues. In the taenia coli, the Na-free solution increases the influx of $\mathrm{Ca}$ ion (BÜLBRING and TomITA, 1970) and also suppresses the reabsorption of $\mathrm{Ca}$ ion from the myoplasm (MAGARIBUCHI and Kuriyama, 1972; SAKAMOTO and KuriYama, 1971), thus causing enhancement of the amplitude of the tonic response, but isoprenaline does not have any effect. On the other hand, in the vas deferens, the Na-free solution does not enhance the 
amplitude of the tonic response of the contracture, but isoprenaline has no effect.

It was suggested by others that $\mathrm{Ca}$ ion releasing mechanisms which cause contracture may be different with excess $\mathrm{K}$-solution and with acetylcholine (EvANS et al., 1958; SCHILD, 1967; Hurwitz et al., 1967; VAN BreEMEN and DANiel, 1966). However, in the vas deferens the tonic response of the contracture was not modified by treatment with acetylcholine. Therefore, the same mechanism for release of $\mathrm{Ca}$ ions may occur with excess K-Krebs and with acetylcholine. Furthermore, the results suggest that a similar ionic mechanism might be involved in the actions of noradrenaline and acetylcholine.

EBASHI and ENDO (1968) have reviewed the mechanical properties of the contractile proteins in relation to $\mathrm{Ca}$ ion. They postulate that the amplitude of the tonic response is determined by an equilibrium concentration of free $\mathrm{Ca}$ ion in the myoplasm reflecting the release and reabsorption of $\mathrm{Ca}$ ion from the reticulum in the skeletal muscle. The amplitude of the phasic response is directly related to the membrane potential level, but the amplitude of the tonic response is not directly related. In the vas deferens, the relaxation time is very short and the amplitude of the tonic response is low, indicating high activity of the reabsorption process for $\mathrm{Ca}$ ion from the myoplasm.

In the excess K-Krebs solution (29.5-59 mM), isoprenaline relaxed the tonic response of the contracture. Isoprenaline might relax the tonic response of the contracture by the acceleration of reabsorption of $\mathrm{Ca}$ ion from the myoplasm with or without suppression of the spiking. The influx of $\mathrm{Ca}$ ion from the external medium in the myoplasm is thought to be the main source for the tonic response of the contracture in the vas deferens, since under treatment with equivalent concentration of $\mathrm{La}$ ion for $\mathrm{Ca}$ ion, the tonic response is completely inhibited. However, in the taenia coli the tonic response of the contracture is only partly suppressed (MAGARIBUCHI and KURIYAMA, unpublished observations). In many visceral smooth muscles, it was concluded that La ion solely suppressed the influx of $\mathrm{Ca}$ ion into normal and depolarized muscle measured with flux and mechanical methods (Weiss and Goodman, 1969; Goodman and Weiss, 1971). Therefore, strong activity of Ca-reabsorption processes and a small rate of influx of $\mathrm{Ca}$ ion with depolarization of the membrane might maintain the low amplitude of the tonic response of the contracture, thus explaining the lack an effect of isoprenaline on the relaxation of the muscle tone under treatment with excess K-Krebs solution (more than $59 \mathrm{~mm}$ ).

In conclusion, noradrenaline increased the $\mathrm{Na}, \mathrm{K}$ and probably $\mathrm{Ca}$ conductance as the mechanism postulated for the action of acetylcholine on the guinea-pig taenia coli (BüLBRING and KuRIYAMA, 1963). The Cl-conductance under normal conditions might be high and therefore the effects of noradrenaline is suppressed by the $\mathrm{Cl}$ leakage current. Since the replacement of $\mathrm{Cl}$ ion with a less permeable anion, the effects of noradrenaline on the electrical and mechanical activities were enhanced. 
On the other hand, isoprenaline relaxed the amplitude of the phasic contraction partly because of suppression of the spike generation brought about by the outward current pulse, but mainly because of acceleration of reabsorption of free $\mathrm{Ca}$ ion from the myoplasm. The $\alpha$ - and $\beta$-responses of the membrane might not require the activation of $\mathrm{Na}-\mathrm{K}$ active transport mechanism, since ouabain did not modify the actions of noradrenaline and isoprenaline on the smooth muscle of vas deferens.

\section{REFERENCES}

Brading, A. F., Bülbring, E. and Tomita, T. (1969) The effect of sodium and calcium on the action potential of the smooth muscle of the guinea-pig taenia coli. J. Physiol., 200: 637-654.

BülBRING, E. and KuRIYAMA, H. (1963) Effects of changes in ionic environment on the action of acetylcholine and adrenaline on the smooth muscle of guinea-pig taenia coli. J. Physiol., 166: 59-74.

BüLBRING, E. and TomitA, T. (1969a) Increase of membrane conductance by adrenaline in the smooth muscle of guinea-pig taenia coli. Proc. R. Soc. B., 172: 89-102.

BüLBRING, E. and ToMITA, T. (1969b) Suppression of spontaneous spike generation by catecholamines in the smooth muscle of the guinea-pig taenia coli. Proc. R. Soc. B., 172: 103-119.

BüLBRING, E. and TomitA, T. (1969c) Effect of calcium, barium and manganese on the action of adrenaline in the smooth muscle of the guinea-pig taenia coli. Proc. R. Soc. B., 172: $121-136$

BülbRING, E. and TomitA, T. (1970) Effects of Ca removal on the smooth muscle of the guineapig taenia coli. J. Physiol., 210: 217-232.

Burnstock, G. and Holman, M. E. (1966) Junctional potentials at adrenergic synapses. Pharmac. Rev., 18: 481-493.

Caldwell, P. C. (1968) Factors governing movement and distribution of inorganic ions in nerve and muscle. Physiol. Rev., 48: 1-64.

Ebashi, S. and Endo, M. (1968) Calcium ion and muscle contraction. Prog. Biophys. Molec. Biol., 18: 123-183.

Evans, D. H. L., Schild, H. O. and TheslefF, S. (1958) Effects of drugs on depolarized plain muscle. J. Physiol., 143: 474-485.

Goodman, F. R. and WeIss, G. B. (1971) Dissociation by lanthanum of smooth muscle responses to potassium and acetylcholine. Am. J. Physiol., 220: 759-766.

Holman, M. E. (1970) Junction potentials in smooth muscle. In Smooth Muscle, ed. by Büldbring, E., Brading, A., Jones, A. and Tomita, T. Edward Arnold, London, 244-288.

Holman, M. E. and JowetT, A. (1964) Some actions of catecholamines on the smooth muscle of the guinea-pig vas deferens. Austral. J. exp. Biol., 42: 40-53.

HotrA, Y. (1969) Some properties of the junctional and extrajunctional receptors in the vas deferens of the guinea-pig. Agents and Actions, 1: 13-21.

Hurwitz, L., Jornev, P. D. and Von HAGEN, S. (1967) Calcium pools utilized for contraction in smooth muscle. Am. J. Physiol., 213: 1299-1304.

IMAI, S. and TAKEDA, K. (1967). Actions of calcium and certain multivalent cations on potassium contracture of guinea-pig's taenia coli. J. Physiol., 190: 155-170.

KurIYAMA, H. and TomitA, T. (1970) The action potential in the smooth muscle of the guineapig taenia coli and ureter studied by the double sucrose gap method. J. Gen. Physiol., 55: $147-162$. 
LARGE, B. J. (1965) Sympathetic $\beta$-receptors and the guinea-pig vas deferens. Brit. J. Pharmacol., 24: 194-204.

Magaribuchi, T. and KuriYama, H. (1972) Effects of noradrenaline and isoprenaline on the electrical and mechanical activities of the depolarized guinea-pig taenia coli. Jap. J. Physiol., in press.

SAKAMOTO, Y. and KuRIYAMA, H. (1971) The relationship between the electrical and mechanical activity of the guinea-pig stomach. Jap. J. Physiol., 20: 640-656.

SCHIL, H. O. (1967) The action of isoprenaline in the depolarized rat uterus. Brit. J. Pharmac. Chemother., 31: 578-592.

Straub, R. W. (1967) Der Einfluss von lonenpumpen auf das Membranpotential. Bull. Schweiz. Akad. Med. Wiss., 23: 271-276.

TAKAGI, K. and TAKAYANAGI, I. (1965) $\beta$-Adrenergic receptor on the vas deferens of the guineapig. Nature, 206: 308-309.

Urakawa, N. and Holland, W. C. (1964) $\mathrm{Ca}^{45}$ uptake and tissue calcium in K-induced phasic and tonic contraction in taenia coli. Am. J. Physiol., 207: 873-866.

Van Breemen, C. and Daniel, E. E. (1966) The influence of high potassium depolarization and acetylcholine on calcium exchange in the rat uterus. J. Gen. Physiol., 49: 1299-1317.

Weiss, G. B. and Goodman, F. R. (1969) Effects of lanthanum on contraction, calcium distribution and $\mathrm{Ca}^{45}$ movements in intestinal smooth muscle. J. Pharmacol. Exptl. Therap., 169: $46-55$. 